\title{
Sedimentation of particulate material in stratified and nonstratified water columns in the Bombay High area of the Arabian Sea
}

\author{
Narayan B. Bhosle, Subhash S. Sawant, Prabha D. Sankaran, Arun B. Wagh
}

National Institute of Oceanography, Dona Paula - 403 004, Goa, India

\begin{abstract}
Sedimentation of particulate material at 22, 42 and $62 \mathrm{~m}$ was recorded at a station in the Bombay High area of the Arabian Sea from September 1985 to March 1986. Diatom numbers and physical structure, especially thermal stratification, played an important role in controlling both magnitude of total flux and nature of sedimented material. Changes in suspended diatom numbers were, with some exceptions, reflected in the sedimented material caught by the traps. From September to March, mean sedimentation of total particulate material (TPM) and particulate inorganic material (PIM) increased with depth. Up to December, particulate organic carbon (POC), particulate organic nitrogen (PON), particulate biogenic silica (PSi), chlorophyll a equivalents (Chl a equiv.), total particulate carbohydrates (TCHO) and the constituent fractions dilute alkali-soluble (AL-CHO) and residual carbohydrates ( $\mathrm{RS}-\mathrm{CHO}$ ) increased and dilute acid-soluble carbohydrates (AC-CHO) decreased with depth. From January to March, however, mean sedimentation rates of POC, PON, PSi and Chl a equiv. generally decreased with depth, whereas sedimentation fluxes of TCHO, AC-CHO, AL-CHO and RS$\mathrm{CHO}$ decreased between 22 and $42 \mathrm{~m}$ and increased again at $62 \mathrm{~m}$. Low POC/Chl a equiv. and POC/PSi ratios indicate that fairly fresh biogenic material settled during January to March when the water column was more or less homogeneous, as compared to September to December when the water column was thermally stratified. Sedimentation of organic carbon was correlated with sedimentation of biogenic silica, especially during January to March. There were positive and highly significant relationships between the flux of TCHO and those of TPM, POC, Chl a equiv. and PSi. From the latter 2 relationships, it was deduced that diatoms were the major source of TCHO at this station. High sedimentation of TPM was associated with high flux of organic carbon and TCHO. This may have a stimulatory effect on benthic organisms and may also enhance the chances of burial of organic matter in sediments.
\end{abstract}

\section{INTRODUCTION}

Recently, there has been growing interest in the measurement of particle flux to the sea floor in order to improve understanding of biological and geochemical processes in marine environments. Sediment traps have been used widely to assess the flux of particles in various aquatic environments. Seasonal variability in total particle flux has been found to parallel the typical seasonal pattern of primary productivity in surface water (Deuser \& Ross 1980, Deuser et al. 1981, Honjo 1982). Particle flux attains its maximum within days to weeks after surface phytoplankton blooms, suggesting rapid transport of particles. Large particles such as faecal matter, faecal pellets and amorphous aggregates of small particles including phytoplankton cells ('marine snow') have been implicated as important vehicles for the rapid transport of organic matter to the sea floor (Deuser \& Ross 1980, Deuser et al. 1981, Honjo 1982, Asper 1987). These rapidly sinking particles form an important source of supply of organic matter, produced in the upper sunlit waters, to marine sediments and benthic organisms. Seasonal supply of high nutritional quality organic matter has a profound effect on the growth and reproduction of shallow (Graf et al. 1982, 1983, Smetacek 1984) and deep water benthic organisms (Billett et al. 1983).

In the open ocean, the particle flux is often dominated by biogenic particles (Honjo 1978, Deuser \& Ross 1980, Deuser et al. 1981). Terrestrial particles and resuspension of bottom sediments may influence the flux of particles in shallow coastal and shelf environments (Degens \& Ittekkot 1985, Nelson et al. 1987). Rapid mass sedimentation of phytoplankton blooms has been reported for many coastal and shelf localities (Smetacek 1984, 1985, Skjoldal \& Wassmann 1986. 
Harding et al. 1987) and is generally related to low biomass of zooplankton (Smetacek 1984, Harding et al. 1987). Thus, in the absence of effective grazing by zooplankton, a large part of the phytoplankton bloom sinks out from the euphotic zone. The process of algal cell sinking is not well known, but nutrient starvation, light deficiency and a generally deteriorated physiological state are perhaps involved (Smetacek 1985 Skjoldal \& Wassmann 1986). Furthermore, seasonal changes in physical properties such as temperature, water density, wind and currents are accompanied by alteration of mixed layer depth. Changes in mixed layer depth are expected to modify nutrient supply to the euphotic layer thereby controlling algal production and/or concentrations (Ryther et al. 1966, Banse 1984, 1986). Physical processes controlling phytoplankton development may also influence the magnitude of total mass flux and its nature in shallow marine environments (Hargrave \& Taguchi 1978, Wassmann 1985, Harding et al. 1987).

To our knowledge, no data on sedimentation of particulate material in the coastal and shelf waters of the Arabian Sea has previously been available. In this paper, data on the sedimentation of particulate material in thermally stratified and non-stratified water columns at a station in the Arabian Sea are presented and discussed.

\section{AREA OF INVESTIGATION}

The study site $\left(19^{\circ} 20^{\prime} \mathrm{N}, 71^{\circ} 20^{\prime} \mathrm{E}\right)$ is located in the Bombay High region of the Arabian Sea, about $160 \mathrm{~km}$ off Bombay which is a highly industrialized and one of the most populous (8 million) cities in India (Fig. 1) This area has lately been subjected to intensive oil exploration and exploitation activities. The region experiences a slight excess of precipitation over evaporation $(>20 \mathrm{~cm}$ ) annually. Surface circulation is influenced by 2 monsoons. During the southwest (SW) summer monsoon (June to September) there is a clockwise current system, and during the northeast (NE) winter monsoon (October to May), an anti-clockwise system. The current system during the SW monsoon is reinforced by the stronger winds ( 25 to 30 knots) One of the most important features of the SW monsoon is the upwelling along the coasts of Somalia, Arabia and southwest India (Sastry \& D'Souza 1972). Surface waters exhibit a bimodal temperature pattern over the year with lows in the winter and during the summer (SW) monsoon (Shetye 1986). Temperature changes are accompanied by alteration of mixed layer depth due to change of water density and/or wind action (Banse 1984, 1986). Upwelling along the coast may also influence the mixed layer depth. Seasonal variations in

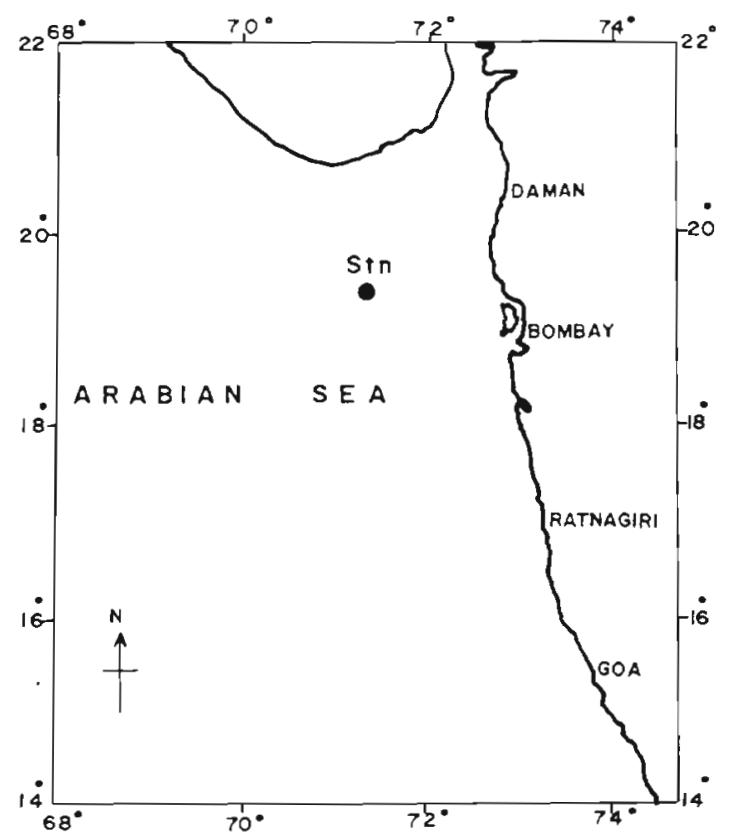

Fig. 1. Study area showing the location of the station in the Bombay High region of the Arabian Sea

the current, wind and mixed layer depth are expected to influence nutrient supply to the surface layer and may have direct implication on algal production and/or concentrations (Ryther et al. 1966, Banse 1984, 1986).

\section{MATERIALS AND METHODS}

The observations were carried out at a single sampling station (Fig. 1) with a water depth of about $78 \mathrm{~m}$. Nansen and/or Niskin water samplers were used for discrete water sampling. Temperature was recorded with a reversing thermometer. Salinity and dissolved oxygen were determined by titration methods (Strickland \& Parsons 1972).

Water samples $(100 \mathrm{ml})$ of phytoplankton were preserved with $5 \mathrm{ml}$ of Kiefers solution (Carlberg 1972) Subsamples (10 to $50 \mathrm{mll}$ ) were transferred to sedimentation tubes for $24 \mathrm{~h}$. The supernatant water was discarded and diatom cells were counted and identified using an inverted microscope (Parsons et al. 1984) Replicate analysis of samples gave a coefficient of variation of about 26 to $30 \%$ for total diatom counts.

Settling particles were intercepted using PVC cylindrical sediment traps. Each trap had a diameter of ca $100 \mathrm{~mm}$ (height:diameter ratio, 3:1). The traps were deployed during 7 periods ranging from 25 to $36 \mathrm{~d}$ in September 1985 to March 1986. Generally duplicate or triplicate traps were used at the same depth to compare the variability between replicate traps (Table 1). A hexagonal steel frame with 2 or 3 traps (fixed using 
Table 1. Sedimentation rates ( $\mathrm{mg} \mathrm{\textrm {m } ^ { - 2 }} \mathrm{d}^{-1}$ ) of total particulate matter (TPM) and their variability observed with replicate traps during various periods of deployment

\begin{tabular}{|c|c|c|c|c|c|c|c|c|c|c|c|c|c|}
\hline \multirow[t]{2}{*}{ Date } & \multirow{2}{*}{$\begin{array}{l}\text { Exposure } \\
\text { period } \\
\text { (d) }\end{array}$} & \multicolumn{4}{|c|}{$22 \mathrm{~m}$} & \multicolumn{4}{|c|}{$42 \mathrm{~m}$} & \multicolumn{4}{|c|}{$62 \mathrm{~m}$} \\
\hline & & Flux & $\mathrm{x}$ & $\mathrm{SD}$ & $\mathrm{CV}$ & Flux & $\mathrm{X}$ & $\mathrm{SD}$ & $\mathrm{CV}$ & Flux & $\mathrm{X}$ & SD & $\mathrm{CV}$ \\
\hline 30 Sep to 29 Oct 1985 & 29 & $\begin{array}{l}2972 \\
3636\end{array}$ & 3304 & 332 & 10.0 & $\begin{array}{l}4312 \\
4832\end{array}$ & 4572 & 260 & 5.6 & $\begin{array}{l}3663 \\
5257\end{array}$ & 4460 & 797 & 17.8 \\
\hline 29 Oct to 23 Nov & 25 & $\begin{array}{l}2537 \\
2498 \\
1940\end{array}$ & 2325 & 272 & 11.7 & $\begin{array}{l}6235 \\
5052 \\
4845\end{array}$ & 5377 & 612 & 11.3 & $\begin{array}{l}7412 \\
3173 \\
5423\end{array}$ & 5336 & 1731 & 32.4 \\
\hline 23 Nov to 31 Dec & 38 & $\begin{array}{l}1245 \\
1547\end{array}$ & 1396 & 151 & 10.8 & $\begin{array}{l}1992 \\
1985 \\
2211\end{array}$ & 2062 & 104 & 5.0 & $\begin{array}{l}3590 \\
6138 \\
5384\end{array}$ & 5037 & 1068 & 21.2 \\
\hline 31 Dec to 31 Jan 1986 & 31 & $\begin{array}{l}5676 \\
2947\end{array}$ & 4311 & 1364 & 31.6 & $\begin{array}{l}3065 \\
2777\end{array}$ & 2921 & 144 & 4.9 & $\begin{array}{l}5103 \\
7162\end{array}$ & 6132 & 1029 & 16.7 \\
\hline 31 Jan to 1 Mar & 29 & $\begin{array}{l}11810 \\
12606\end{array}$ & 12208 & 398 & 3.2 & $\begin{array}{l}7400 \\
8363\end{array}$ & 7881 & 481 & 6.1 & $\begin{array}{r}9847 \\
11823\end{array}$ & 10835 & 988 & 9.1 \\
\hline $1 \mathrm{Mar}$ to $6 \mathrm{Apr}$ & 36 & $\begin{array}{l}3926 \\
3200\end{array}$ & 3563 & 363 & 10.2 & $\begin{array}{l}2984 \\
5402\end{array}$ & 4193 & 1209 & 28.8 & $\begin{array}{l}7467 \\
7715\end{array}$ & 7591 & 124 & 1.6 \\
\hline
\end{tabular}

clamps), was kept suspended at depths of 22, 42 and $62 \mathrm{~m}$ from an offshore oil production platform. Deployment and retrieval of the traps were carried out using a pneumatically operated winch. Chloroform was added to the traps beforehand to reduce decomposition of organic matter.

After retrieval, the material collected in each trap was passed through $300 \mu \mathrm{m}$ gauze to remove larger zooplankton and then suspended in a known volume of filtered seawater and split for the analyses described below.

A known volume was filtered through ignited $\left(450^{\circ} \mathrm{C}, 3 \mathrm{~h}\right)$ and preweighed GF/C glass filters, desalted by repeated washing with distilled water, dried at $40^{\circ} \mathrm{C}$ for $24 \mathrm{~h}$ and weighed to obtain total particulate material (TPM). The fraction of particulate organic material (POM) was determined by weight loss on ignition at $450^{\circ} \mathrm{C}$ for $3 \mathrm{~h}$ (Dean 1974). The content of particulate inorganic material (PIM) was then calculated by difference (PIM = TPM - POM). Particulate organic carbon (POC) was analysed following the method of Strickland \& Parsons (1972). Particulate organic nitrogen (PON) was determined following the method of Smart et al. (1983). Particulate biogenic silica (PSi) was extracted with $0.05 \% \quad \mathrm{Na}_{2} \mathrm{CO}_{3}$ (Anderson 1986) and analysed as suggested by Strickland \& Parsons (1972). Chlorophyll $a$ and phaeopigments were extracted with $90 \%$ acetone and determined spectrophotometrically (Strickland \& Parsons 1972). Results are expressed as chlorophyll a equivalents (Chl a equiv.) as described by Smetacek (1980). Total particulate carbohydrates ( $\mathrm{TCHO}$ ) and the constituent frac- tions dilute acid-soluble ( $\mathrm{AC}-\mathrm{CHO}$ ), alkali-soluble (AL$\mathrm{CHO}$ ) and residual (RS-CHO) carbohydrates were analysed by the phenol-sulphuric acid method as described earlier (Bhosle \& Dhople 1988, Bhosle \& Wagh 1989). The coefficient of variation of the analytical methods used for PIM, POM, POC, PON, TCHO and PSi based on 6 replicate analyses was $0.49,2.08$, $2.40,4.24,4.90$ and $6.50 \%$, respectively.

A subsample was preserved with buffered formalin (5\%) (Wassmann 1983, Liebezeit \& Bodungen 1987) for microscopic observation.

\section{RESULTS}

\section{Hydrography}

The euphotic zone was about $20 \mathrm{~m}$ and $16 \mathrm{~m}$ deep in the periods September to December and January to March, respectively (Venugopalan 1988). Temperature has a profound influence in controlling the vertical mixing of the water column (Fig. 2A). Temperature of the surface water was high and generally decreased with depth. From September to December, the water column was stratified, with homogeneous temperature in the upper 20 to $38 \mathrm{~m}$. From December onward, with the development of cold and dry northeast winds (Antony pers. comm.), the surface water temperature declined. The effect of this winter cooling penetrated to $70 \mathrm{~m}$, making the water column thermally homogeneous from January to March. Surface salinity was high during September and low in December and generally 


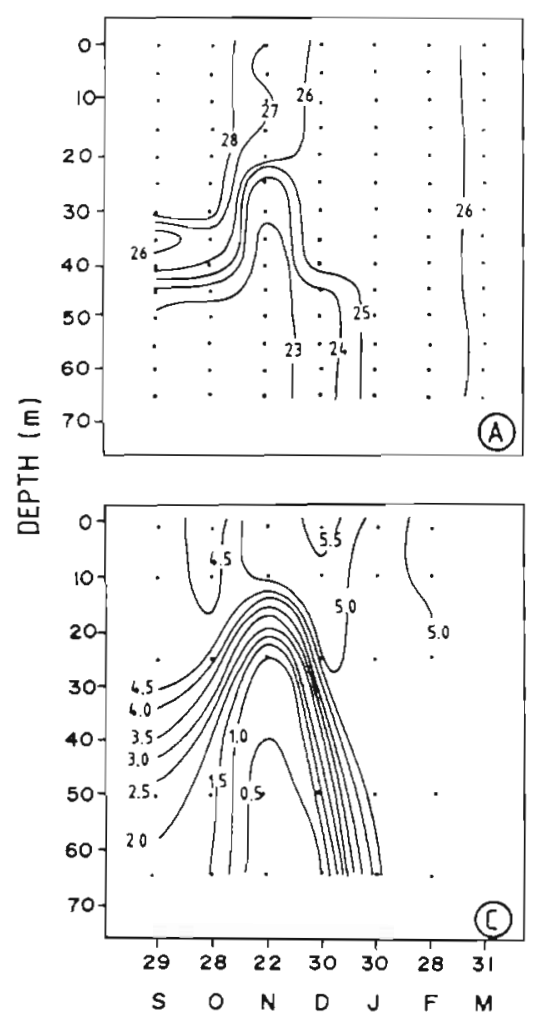

decreased with depth (Fig, 2B). Dissolved oxygen was high in the surface water and decreased with depth in the period September to December, Rather uniform high concentrations of dissolved oxygen in the water column were observed from January to March (Fig, 2C).

During the SW monsoon the coastal current runs clockwise and the deep subsurface water upslopes onto the shelf of Africa, Arabia and southwest India (Ryther et al. 1966, Banse 1984, 1986). The upsloped water persists on the shelf off Bombay well into November (the NE monsoon period) as was evident from the distribution of temperature and dissolved oxygen (Fig. 2A, C).

\section{Diatoms}

Observations carried out at this station since 1984 suggest that diatom numbers were generally low during September to November (Kelkar unpubl.). A many-fold increase in diatom numbers was observed in December to February (Fig. 2D). This was followed by a decrease in March to cell numbers fairly similar to those observed in September to November. The distribution of diatoms in the upper $10 \mathrm{~m}$ seems to parallel that of chlorophyll a (Venugopalan 1988). He observed low concentrations of chlorophyll $a$ in September to November (ca 0.04 to $0.06 \mathrm{ug} \mathrm{l}^{-\mathrm{i}}$ ) and high concentrations in December to February (ca 0.30 to $0.50 \mathrm{ug} \mathrm{l}^{-1}$ ).
Fig. 2. Distribution of $\mathrm{A}$ : temperature $\left({ }^{\circ} \mathrm{C}\right) ; \mathrm{B}$ : salinity (\%); C: oxygen ( $\left.\mathrm{ml} \mathrm{l}^{-1}\right)$; and $\mathrm{D}$ : diatom numbers (cells ml ${ }^{-1}$ ) during September 1985 to March 1986

Cell numbers generally decreased with depth in the September to December period. Also in January and February their numbers decreased in the upper $25 \mathrm{~m}$, but below this depth they were rather homogeneous with a slight increase at $50 \mathrm{~m}$.

The genera Navicula, Rhizosolenia and Coscinodiscus were most abundant in the water column during September to November. From December to February Rhizosolenia, Nitzschia and Chaetoceros were most abundant.

\section{Sedimentation}

\section{Sedimentation in relation to depth}

There were some differences in sedimentation in relation to depth. To illustrate this, we have divided the investigation into 2 periods, September to December when the water column was thermally stratified and January to March when the water column was more or less homogeneous or nonstratified (Fig. 2). Mean sedimentation of TPM, PIM, POC, PON and PSi increased with depth in the stratified period, whereas Chl a equiv., after an increase at $42 \mathrm{~m}$, decreased below this depth (Fig. 3). In contrast, mean sedimentation rates were higher and generally decreased with increasing depth during the nonstratified period, except for TPM and PIM which increased (Fig. 3). 

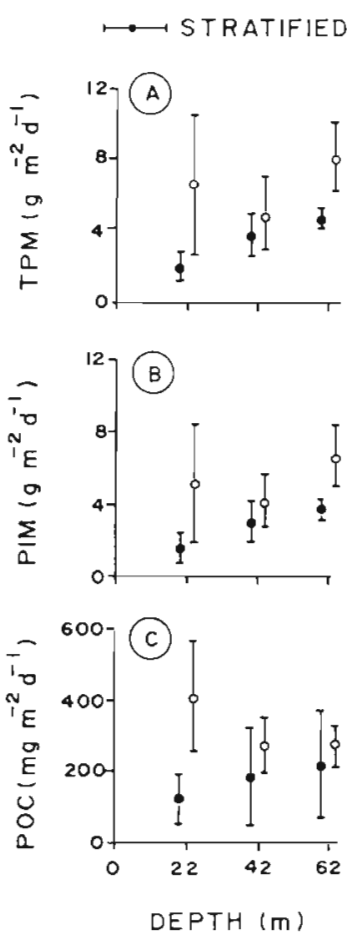

Fig. 3. Mean sedimentation rates of $A$ : total particulate material (TPM); B: particulate inorganic material (PIM); C: particulate organic carbon (POC); D: particulate organic nitrogen (PON); E: chlorophyll a eqivalents ( $\mathrm{Chl}$ a equiv.); and F: particulate biogenic silica (PSi) in the stratified (•) and non stratified (O) periods. Bars represent $2 \mathrm{SD}$

During the stratified period the pattern of mean sedimentation fluxes of $\mathrm{TCHO}$ and the constituent fractions, except for AC-CHO (Table 2), was similar to that of TPM, PIM, POC, PON and PSi observed during this period. In contrast, mean fluxes of TCHO and the constituent fractions decreased between 22 and $42 \mathrm{~m}$ and increased again at $62 \mathrm{~m}$ during the nonstratified period.

Sedimentation of the measured components in the nonstratified period, as a percentage of sedimentation during the total period, was high and varied from 63.9 to $91.7 \%$ at $22 \mathrm{~m}$ and from 38.7 to $71.1 \%$ at $62 \mathrm{~m}$ (Table 3). The percentage sedimentation in the nonstratified period was particularly high for PSi (64.1 to $91.7 \%$ ) and Chl a equiv. (51.8 to $90.0 \%$ ). The percentage sedimentation in the nonstratified period tended to decrease between 22 and $62 \mathrm{~m}$.

The extent to which sedimentation differed vertically in the water column can be assessed by analysing the coherence between seasonal sedimentation rates at various depths expressed by the product moment correlation coefficient (Sokal \& Rolf 1981, Wassmann 1985, Skjoldal \& Wassmann 1986) (Table 4). Highly significant correlation coefficients were observed between 22 $\mathrm{m}$ and 42 and $62 \mathrm{~m}$ for TPM, PIM, POM, PSi, Chl a equiv. and TCHO. There was no significant correlation between 22 and $62 \mathrm{~m}$ for POC, nor between 22 and 62 $\mathrm{m}$ and 42 and $62 \mathrm{~m}$ for PON. This suggests that most of the sedimentation rates at succeeding depths were closely related. The observed insignificant correlations for POC and PON were probably due to sedimentation of resuspended organic matter.

\section{Temporal pattern of sedimentation}

Seasonality was observed in the sedimentation of TPM, POC, Chl a equiv, PSi, TCHO and its constituent fractions (Figs. 4 and 5). Sedimentation rates were relatively low in the stratified period. Thereafter, they generally increased during the nonstratified period and reached a maximum in February. An increase in sedimentation of POC and TCHO in November was observed. The pattern of sedimentation rates implies that the periods with stratified and nonstratified water columns (Fig. 2) were characterized by low and high rates, respectively.

Table 2. Sedimentation of carbohydrates and constituent fractions during stratified (September to December) and non-stratified (January to March) periods. TCHO; total particulate carbohydrates; AC-CHO: dilute acid-soluble carbohydrates; AL-CHO: dilute alkali-soluble carbohydrates; RS-CHO: residual carbohydrates; TPM: total particulate material; POC: particulate organic carbon. Mean values $\pm \mathrm{SD}$

\begin{tabular}{|c|c|c|c|c|c|c|}
\hline \multirow[t]{2}{*}{ Parameter } & \multicolumn{3}{|c|}{ Stratified period } & \multicolumn{3}{|c|}{ Nonstratified period } \\
\hline & $22 \mathrm{~m}$ & $42 \mathrm{~m}$ & $62 \mathrm{~m}$ & $22 \mathrm{~m}$ & $42 \mathrm{~m}$ & $62 \mathrm{~m}$ \\
\hline $\mathrm{TCHO}\left(\mathrm{mgC} \mathrm{m}^{-2} \mathrm{~d}^{-1}\right)$ & $18.68 \pm 12.36$ & $19.88 \pm 10.64$ & $25.76 \pm 7.56$ & $61.72 \pm 33.76$ & $37.96 \pm 13.24$ & $58.36 \pm 13.28$ \\
\hline $\mathrm{AC}-\mathrm{CHO}\left(\mathrm{mgC} \mathrm{m}^{-2} \mathrm{~d}^{-1}\right)$ & $4.40 \pm 3.16$ & $4.28 \pm 1.96$ & $3.88=1.04$ & $13.44 \pm 7.28$ & $7.48 \pm 4.00$ & $10.92 \pm 2.00$ \\
\hline $\mathrm{AL}-\mathrm{CHO}\left(\mathrm{mgC} \mathrm{m}^{-2} \mathrm{~d}^{-1}\right)$ & $3.60 \pm 4.04$ & $3.92 \pm 3.28$ & $4.28 \pm 0.80$ & $15.64 \pm 12.00$ & $10.88 \pm 5.28$ & $13.16 \pm 3.92$ \\
\hline $\mathrm{RS}-\mathrm{CHO}\left(\mathrm{mgC} \mathrm{m}^{-2} \mathrm{~d}^{-1}\right)$ & $10.65 \pm 5.48$ & $11.66 \pm 7.18$ & $17.60 \pm 6.49$ & $32.65 \pm 14.62$ & $19.52 \pm 4.06$ & $34.24 \pm 7.52$ \\
\hline TCHO-C/TPM $(\%)$ & $1.00 \pm 0.48$ & $0.53 \pm 0.20$ & $0.52 \pm 0.12$ & $0.92 \pm 0.08$ & $0.76 \pm 0.08$ & $0.72 \pm 0.02$ \\
\hline TCHO-C/POC $(\%)$ & $14.63 \pm 1.84$ & $11.12 \pm 4.94$ & $16.18 \pm 6.91$ & $14.35 \pm 2.35$ & $14.15 \pm 2.96$ & $21.24 \pm 2.48$ \\
\hline $\mathrm{AC}-\mathrm{CHO} / \mathrm{TCHO}(\%)$ & $23.55 \pm 5.40$ & $21.52 \pm 12.82$ & $15.60 \pm 10.64$ & $21.77=3.41$ & $19.70 \pm 3.92$ & $18.71 \pm 1.50$ \\
\hline $\mathrm{AL}-\mathrm{CHO} / \mathrm{TCHO}(\%)$ & $19.27 \pm 7.63$ & $19.71 \pm 11.31$ & $16.61 \pm 3.11$ & $25.34 \pm 5.1$ & $28.66 \pm 4.2$ & $22.54 \pm 1.20$ \\
\hline RS-CHO/TCHO (\%) & $57.01 \pm 9.59$ & $58.65 \pm 11.73$ & $72.47 \pm 6.24$ & $52.90 \pm 6.06$ & $51.42 \pm 6.49$ & $58.67 \pm 1.96$ \\
\hline
\end{tabular}


Table 3. Sedimentation ( $\mathrm{g} \mathrm{m}^{-2}$ ) during January to March as percentage of sedimentation from September to March. TPM: total particulate material, PIM: particulate inorganic material; POM: particulate organic material; POC and PON: particulate organic carbon and nitrogen; PSi: particulate biogenic silica: Chl a equiv.: chlorophyll a plus phaeopigments; TCHO: total particulate carbohydrates

\begin{tabular}{|lccc|}
\hline Component & \multicolumn{3}{c}{$\begin{array}{l}\text { Sedimentation (Jan-Mar / Sep-Mar) } \\
\end{array}$} \\
& $22 \mathrm{~m}$ & $42 \mathrm{~m}$ & $62 \mathrm{~m}$ \\
\hline TPM & 71.2 & 49.5 & 55.5 \\
PIM & 70.5 & 48.2 & 55.6 \\
POM & 73.9 & 55.1 & 55.4 \\
POC & 71.2 & 53.1 & 48.9 \\
PON & 63.9 & 54.2 & 38.7 \\
PSi & 91.7 & 80.5 & 64.1 \\
Chl a equiv. & 90.0 & 51.8 & 71.1 \\
TCHO & 71.5 & 57.6 & 61.2 \\
\hline
\end{tabular}

Table 4. Product moment correlation coefficients ( $\mathrm{r}$ ) comparing seasonal sedimentation rates of total particulate material (TPM); particulate inorganic material (PIM); particulate organic material (POM); particulate organic carbon (POC); particulate organic nitrogen (PON); particulate biogenic silica (PSi); chlorophyll a equivalents (Chl a equiv.); and total particulate carbohydrates (TCHO) at 22,42 and $62 \mathrm{~m}$ depth ( $\mathrm{n}=7$ )

\begin{tabular}{|c|c|c|c|}
\hline \multirow[t]{2}{*}{ Component } & \multirow{2}{*}{$\begin{array}{l}\text { Depth } \\
(\mathrm{m})\end{array}$} & \multicolumn{2}{|c|}{ Depth $(m)$} \\
\hline & & 42 & 62 \\
\hline \multirow[t]{2}{*}{ TPM } & 22 & $0.82 \cdots$ & $0.92 \cdots$ \\
\hline & 42 & & $0.74^{\cdots}$ \\
\hline \multirow[t]{2}{*}{ PIM } & 22 & $0.82 \cdots$ & $0.92 \cdots$ \\
\hline & 42 & & 0.71 \\
\hline \multirow[t]{2}{*}{ POM } & 22 & $0.81^{\cdots}$ & $0.90 \cdots$ \\
\hline & 42 & & $0.84 \cdots$ \\
\hline \multirow[t]{2}{*}{$\mathrm{POC}$} & 22 & $0.70^{\circ}$ & 0.58 \\
\hline & 42 & & $0.97 \cdots$ \\
\hline \multirow[t]{2}{*}{ PON } & 22 & $0.91 \cdots$ & 0.20 \\
\hline & 42 & & 0.54 \\
\hline \multirow[t]{2}{*}{ PSi } & 22 & $0.90^{\cdots} \cdots$ & $0.90^{\cdots} \cdots$ \\
\hline & 42 & & $0.80 \cdots$ \\
\hline \multirow[t]{2}{*}{ Chl a equiv. } & 22 & $0.86 \cdots$ & $0.89 \cdots$ \\
\hline & 42 & & $0.92 \cdots$ \\
\hline \multirow[t]{2}{*}{$\mathrm{TCHO}$} & 22 & $0.89 \cdots$ & $0.94 \cdots$ \\
\hline & 42 & & $0.84^{\cdots} \cdots$ \\
\hline
\end{tabular}

Nature of sedimented material

Microscopic examination (qualitative) revealed that most of the material collected in the sediment traps consisted of detrital material and a number of identifiable diatoms. Some copepod faecal pellets were also found in the traps in the stratefied period, while they were rarely present during the nonstratified period. Diatoms such as Chaetoceros, Coscinodiscus, Navicula, Nitzschia and Rhizosolenia, which were most abundant
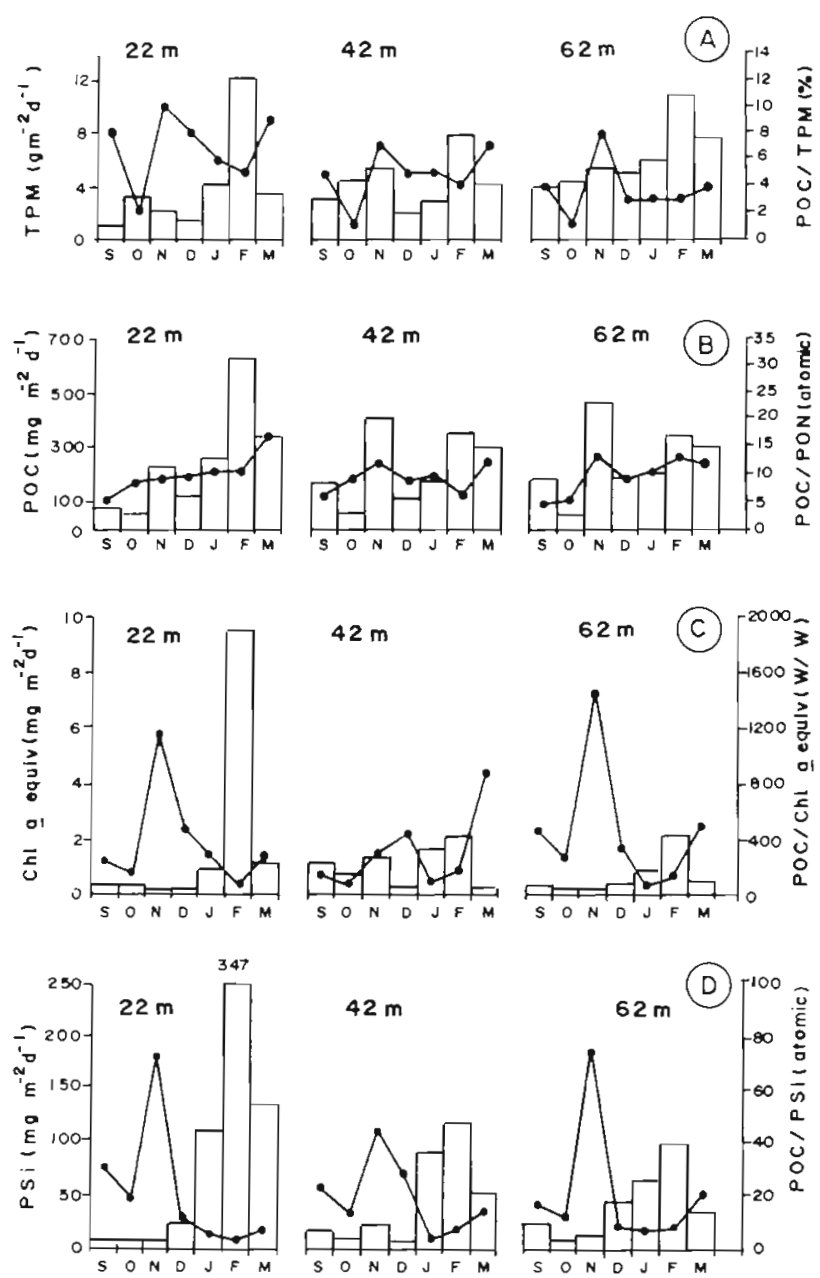

Fig. 4. Sedimentation rates of (left axis, bars) A: total particulate material (TPM); B: particulate organic carbon (POC); C: chlorophyll a equivalents (Chl a equiv); D: particulate biogenic silica (PSi); and (right axis, line graphs) A: POC/TPM (\%); B: POC/PON (atomic); C: POC/Chl a equiv. (wt/wt); D: POC/PSi (atomic) ratios of the sedimented material at 22, 42 and $62 \mathrm{~m}$ from September 1985 to March 1986

in the water column, were also generally found in the traps at all the depths. Amongst these, Rhizosolenia, Coscinodiscus and Navicula in the stratified period, and Chaetoceros and Nitzschia in the nonstratified period, were most predominant in the sedimented material.

Although sedimentation rates of PIM were lower during the period of stratification (Fig. 3B), the relative PIM contents of the TPM were quite similar during the 2 periods and varied from 76 to $82 \%$ (Fig. 6A, B). The PIM/TPM ratio tended to increase with depth. The relative POC content of the TPM showed seasonal variation and ranged from 1 to $10 \%$ (Fig. 4A). The POC content of the TPM showed a general decrease with increasing depth (Fig. 6A, B). The mean POC content of the TPM was 4 to $7 \%$ and 3 to $5 \%$ in the stratified and nonstratified periods, respectively. 


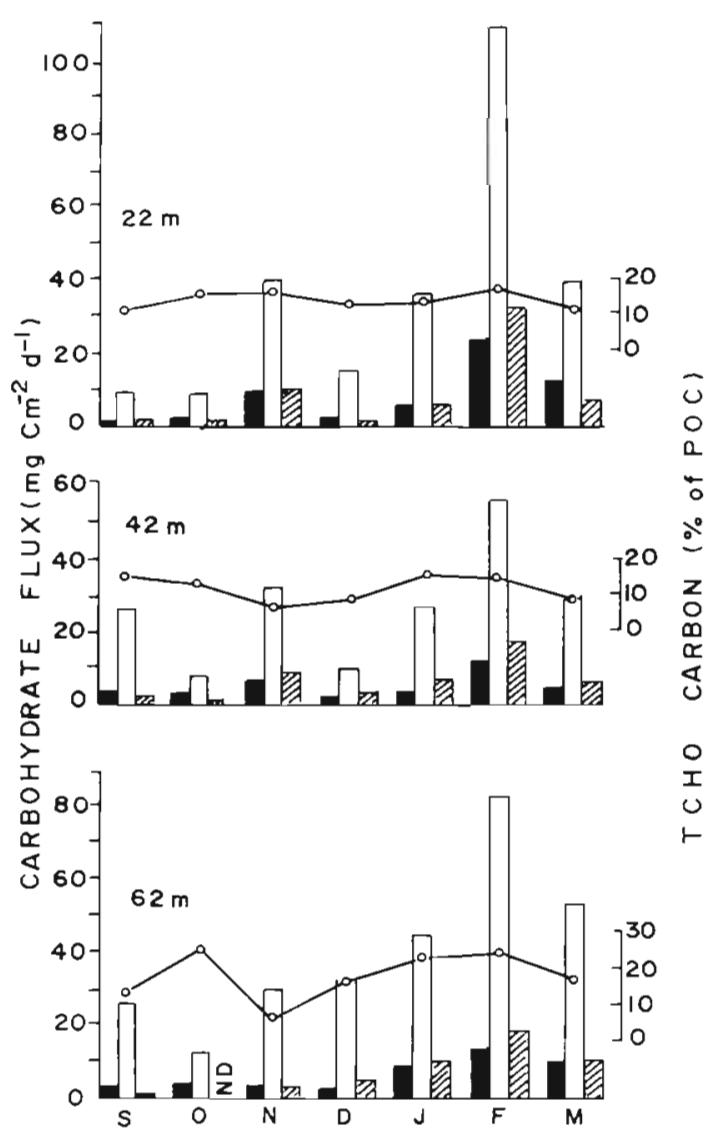

Acid-soluble $\square$ Total Alkali-soluble

Fig. 5. Sedimentation rates of total particulate, dilute acidsoluble, alkali-soluble, carbohydrates, and the total particulate carbohydrates (TCHO-C)/particulate organic carbon (POC) ratio (\%) of the sedimented material at 22,42 and $62 \mathrm{~m}$ during September 1985 to March 1986

The POC/PON (atomic) ratio of the sedimented material showed modest variations with season (Fig. 4B) and depth (Fig. 6C, D), suggesting changes in the composition of the organic matter and/or resuspension of bottom sediments.

The POC/Chl a equiv. (wt/wt) ratio was high during November and December and somewhat lower in September and October (Fig. 4C). The ratio was lowest in January-February and increased again in March (Fig. 4C). The organic matter deposited during the peak sedimentation in February was rich in plant pigments and had lowest POC/Chl a equiv. ratios (65 to 143) (Fig. $4 \mathrm{C})$. The mean POC/Chl a equiv. ratio for the stratified period decreased from 22 to $42 \mathrm{~m}$ and increased again at $62 \mathrm{~m}$ (Fig. 6C). The mean ratio showed the reverse trend for the nonstratified period (Fig. 6D).

The POC/PSi (atomic) ratio was high during the stratified period and low during the nonstratified period (Fig. 4D). The mean ratio showed no marked trend with depth for the stratified period, whereas it increased with depth for the nonstratified period (Fig. 6C, D). There was a good correlation between sedimentation rates of PSi and POC throughout the water column for the entire sampling period (Fig. 7). This relationship was highly significant $(p<0.001)$ for the nonstratified period.

The TCHO-C/TPM and AC-CHO/TCHO ratios decreased with depth (Table 2). The TCHO-C/POC ratio was higher at 62 than at $22 \mathrm{~m}$ throughout the period of investigation (Table 2). On the other hand, TCHO-C/POC ratio decreased between 22 and $42 \mathrm{~m}$, especially during the stratification period (Table 2). A decrease in $\mathrm{AL}-\mathrm{CHO} / \mathrm{TCHO}$ and an increase in RS$\mathrm{CHO} / \mathrm{TCHO}$ ratios at $62 \mathrm{~m}$ was observed (Table 2). There were positive and highly significant correlations ( $\mathrm{p}<0.001, \mathrm{n}=21$ ) between the fluxes of TCHO and TPM $(r=0.88)$, POC $(r=0.78), C h l$ a equiv. $(r=0.78)$ and PSi $(r=0.81)$.

\section{DISCUSSION}

Sedimentation rates measured with traps represent gross sedimentation rates. These rates include both net or primary sedimentation (particles falling for the first time) and secondary sedimentation (resuspended matter, turbulent upward transport and active transport by animals).

The reliability of data obtained with sediment traps depends on several factors including trap design, hydrodynamic conditions and properties of sedimenting particles (Smetacek et al. 1978, Gardner 1980a, b, Davies \& Payne 1984, Skjoldal \& Wassmann 1986). We employed cylindrical traps with height to diameter ratio of $3: 1$. This aspect ratio has been considered sufficient for minimizing resuspension of trapped particles by water turbulence entering the traps (Bloesch \& Burns 1980, Gardner 1980b). Other studies, however, have shown that the above aspect ratio is in the lower range of ratios which give reliable results (Hargrave \& Burns 1979, Blomqvist \& Kofoed 1981). Furthermore, the traps, suspended at 22, 42 and $62 \mathrm{~m}$, might have been influenced by variable hydrodynamic conditions. The few current measurements carried out in the study area (Anthony pers. comm.) suggest that the $22 \mathrm{~m}$ traps were perhaps subjected to greater water exchange between the traps and their surroundings than the 42 and $62 \mathrm{~m}$ traps and thus might have underestimated sedimentation rates. On the other hand, sedimentation traps at $62 \mathrm{~m}$ might have overestimated the particle flux due to resuspension of bottom sediments.

It is rather difficult to assess the actual influence of hydrodynamic conditions on the trapping efficiency of 


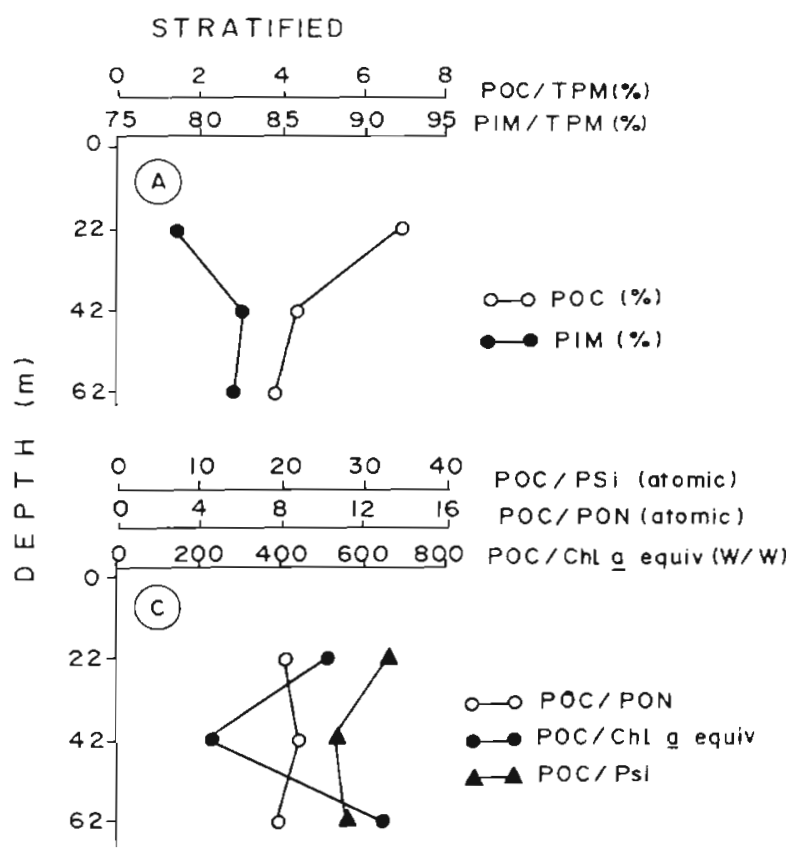

the sedimentation vessels (Bloesch \& Burns 1980, Gardner 1980a, b, Butman 1986). Deployment of replicate traps at the same depth may, however, provide useful information on the accuracy of the data obtained. Data on TPM collected using duplicate or triplicate traps indicated that the coefficient of variation was generally less than $15 \%$ and rarely exceeded $21 \%$ (Table 1). The average coefficient of variation was about $14.34 \%(n=18)$. This is slightly higher than the lower limit of $10 \%$ but well within the higher limit of 20 to $25 \%$ obtained with sediment traps of different

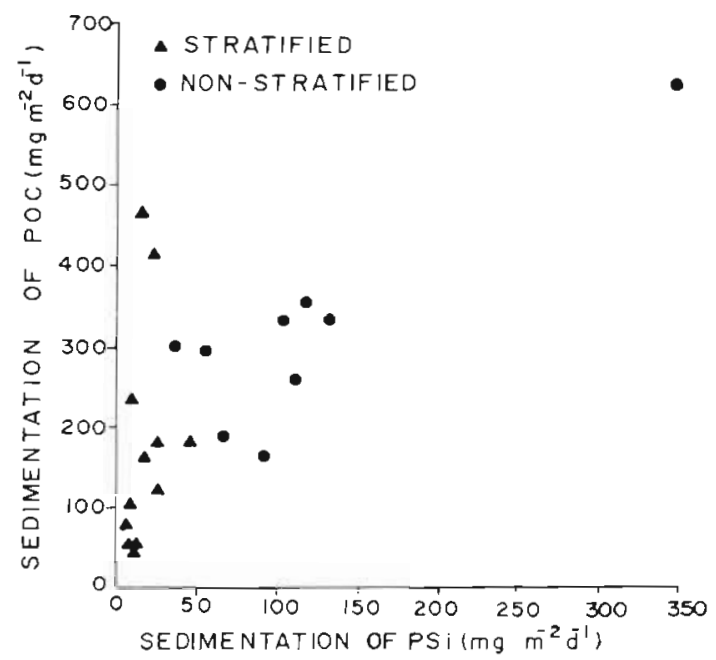

Fig. 7. Relation between sedimentation rates of particulate organic carbon (POC) and particulate biogenic silica (PSi) for the stratified and nonstratified periods. Correlation coefficients $(r)$ were $0.21,0.90$ and 0.75 for the stratified $(n=12)$, nonstratified $(n=9)$ and total period $(n=21)$, respectively
NON-STRATIFIED

\begin{tabular}{ccccc}
0 & 2 & 4 & 6 & 8 \\
75 & 1 & 1 & 1 & 0 \\
\hline
\end{tabular}

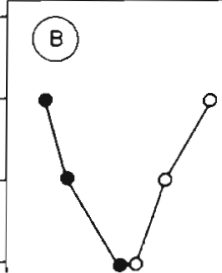

\begin{tabular}{|c|c|c|c|}
\hline 10 & 20 & 30 & 40 \\
\hline 4 & 8 & 12 & 16 \\
\hline
\end{tabular}

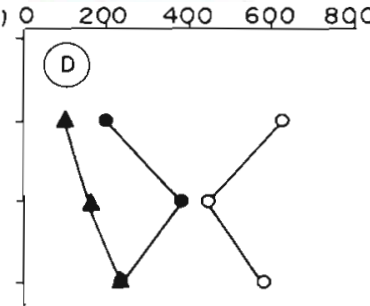

Fig. 6. Vertical profiles of mean ratios characterizing sedimented material for the stratified $(A, C)$ and nonstratified $(B, D)$ periods. $A, B$ : particulate inorganic material (PIM, •) and particulate organic carbon (POC, O) as percentages of total particulate material (TPM); C, D: POC/ Chl a equiv. (•), POC/PON (atomic) (O) and POC/PSi (atomic) («) ratios based on contents of particulate organic carbon (POC), particulate organic nitrogen (PON), particulate biogenic silica (PSi) and chlorophyll a equivalents (Chl a equiv.) designs (Pennington 1974, Hargrave et al. 1976, Kimmel et al. 1977, Prouse \& Hargrave 1977, Davies \& Payne 1984, Bodungen et al. 1986, Nelson et al. 1987).

It could be argued that the seasonality observed in sedimentation rates resulted from contamination originating from the oil production platform and fouling on the inside walls of the sediment traps. Presumably, this has not to a great extent influenced the sedimentation rates. If this was the case, then we would have expected a less consistent set of data with depth and season than was actually found.

During both the periods the mean mass flux of TPM and PIM generally tended to be highest at $62 \mathrm{~m}$ (Fig. $3 \mathrm{~A}, \mathrm{~B})$. Increasing mass flux with depth seems to be a regular feature in many coastal, shelf and slope environments (Hargrave \& Taguchi 1978, Smetacek 1980, Gulliksen 1982, Davies \& Payne 1984, Ducklow et al. 1985, Hargrave \& Phillips 1986, Harding et al. 1987, Liebezeit \& Bodungen 1987, Nelson et al. 1987). The greater quantity of material collected in the bottom traps $16 \mathrm{~m}$ above the sea floor suggest increased resuspension due to increasing turbulent flow near the bottom which would lead to increased particle concentrations near the bottom and subsequently higher rates of trapping.

Decreasing concentration of $\mathrm{POC}$ and TCHO-C (as $\%$ of TPM) with increasing depth observed during both the periods (Fig. 6A, B; Table 2) could be due to loss of carbon by remineralization, ingestion and assimilation of carbon by midwater organisms or through dilution by input of resuspended particles that are lower in organic content.

Sedimentation rates of TPM and POC in different 
Table 5. Daily sedimentation rates of total particulate material (TPM) and particulate organic carbon (POC) and the POC/TPM ratio $(\%)$ in different environments

\begin{tabular}{|c|c|c|c|c|c|}
\hline \multirow[t]{2}{*}{ Location } & \multirow{2}{*}{$\begin{array}{l}\text { Depth of } \\
\operatorname{trap}(\mathrm{m})\end{array}$} & \multicolumn{2}{|c|}{ Sedimentation $\left(\mathrm{g} \mathrm{m}^{-2} \mathrm{~d}^{-1}\right)$} & \multirow{2}{*}{$\begin{array}{c}\mathrm{POC} / \mathrm{TPM} \\
(\%)\end{array}$} & \multirow[t]{2}{*}{ Source } \\
\hline & & TPM & $\mathrm{POC}$ & & \\
\hline $\begin{array}{l}\text { Daparture Bay, B.C., } \\
\text { Canada }\end{array}$ & 30 & 8.22 & 0.55 & 6.7 & Stephens et al. (1967) \\
\hline Loch Ewe, Scottland & 30 & - & 0.16 & - & Steel \& Baird (1972) \\
\hline $\begin{array}{l}\text { St. Margaret's Bay, N.S., } \\
\text { Canada }\end{array}$ & 60 & 4.11 & 0.33 & 7.9 & Webster et al. (1975) \\
\hline $\begin{array}{l}\text { Bedford Basin, N.S., } \\
\text { Canada }\end{array}$ & $\begin{array}{l}20 \\
30 \\
40 \\
50 \\
60\end{array}$ & $\begin{array}{l}2.16 \\
2.69 \\
2.94 \\
2.79 \\
3.71\end{array}$ & $\begin{array}{l}0.16 \\
0.19 \\
0.21 \\
0.20 \\
0.25\end{array}$ & $\begin{array}{l}7.3 \\
7.2 \\
7.2 \\
7.4 \\
6.8\end{array}$ & Hargrave et al. (1976) \\
\hline Northeast Pacific & 50 & - & 0.43 & - & Knauer et al. (1979) \\
\hline Western Kiel Bight, FRG & $\begin{array}{l}15 \\
18\end{array}$ & $\begin{array}{l}1.76-4.60 \\
1.67-4.96\end{array}$ & $\begin{array}{l}0.10-0.22 \\
0.10-0.28\end{array}$ & $\begin{array}{l}4.6-5.9 \\
4.8-6.1\end{array}$ & Smetacek (1980) \\
\hline Fanka Bay, Japan & 40 & $0.56-31.40$ & - & - & Tsunogai et al. (1980) \\
\hline Dabob Bay, WA, USA & 50 & - & 0.19 & - & Lorenzen et al. (1981) \\
\hline Kanehohe Bay, Hawaii & 15 & 5.45 & 0.45 & 8.3 & Taguchi (1982) \\
\hline Lindåspollene & 10 & 1.16 & 0.14 & 12.5 & Wassmann (1983) \\
\hline (fjord), Norway & $\begin{array}{l}20 \\
40 \\
70 \\
85\end{array}$ & $\begin{array}{l}1.47 \\
0.61 \\
0.42 \\
0.40\end{array}$ & $\begin{array}{l}0.30 \\
0.08 \\
0.07 \\
0.06\end{array}$ & $\begin{array}{l}20.5 \\
12.9 \\
16.7 \\
15.6\end{array}$ & \\
\hline Mid Atlantic Bight & 34 & - & 0.34 & - & Falkowski et al. (1983) \\
\hline $\begin{array}{l}\text { Nordåsvannet (fjord), } \\
\text { Norway }\end{array}$ & $\begin{array}{l}20 \\
40 \\
45 \\
50 \\
65\end{array}$ & $\begin{array}{l}1.63 \\
1.34 \\
1.17 \\
1.10 \\
1.06\end{array}$ & $\begin{array}{l}0.23 \\
0.22 \\
0.17 \\
0.17 \\
0.16\end{array}$ & $\begin{array}{l}14.1 \\
16.6 \\
14.5 \\
15.4 \\
15.1\end{array}$ & Wassmann (1985) \\
\hline Mid Atlantic Bight & $\begin{array}{l}10 \\
82 \\
88\end{array}$ & $\begin{array}{c}2.5-12.6 \\
0.10 \\
0.10\end{array}$ & $\begin{array}{l}0.31-0.73 \\
0.008 \\
0.007\end{array}$ & $\begin{array}{c}5.8-18.0 \\
8.0 \\
7.0\end{array}$ & Ducklow et al. (1985) \\
\hline $\begin{array}{l}\text { St. Georges Baya, N.S., } \\
\text { Canada }\end{array}$ & $\begin{array}{r}7 \\
14 \\
21 \\
28\end{array}$ & $\begin{array}{l}2.74 \\
1.51 \\
6.44 \\
7.12\end{array}$ & $\begin{array}{l}0.15 \\
0.27 \\
0.23 \\
0.26\end{array}$ & $\begin{array}{r}5.6 \\
18.4 \\
3.6 \\
3.7\end{array}$ & Harding et al. (1987) \\
\hline $\begin{array}{l}\text { Santa Monica } \\
\text { San Pedro Basin, CA, USA }\end{array}$ & 100 & 0.24 & 0.03 & 14.4 & Nelson et al. (1987) \\
\hline Northwest Pacific & 25 & - & 0.17 & - & Sasaki et al. (1988) \\
\hline Arabian Sea Shelf & $\begin{array}{l}22 \\
42 \\
62\end{array}$ & $\begin{array}{l}1.00-12.20 \\
2.06-7.88 \\
3.98-10.83\end{array}$ & $\begin{array}{l}0.06-0.62 \\
0.06-0.35 \\
0.05-0.46\end{array}$ & $\begin{array}{l}2.0-10.1 \\
1.3-7.7 \\
1.1-8.6\end{array}$ & Present study \\
\hline
\end{tabular}

marine environments have been compiled and presented in Table 5. From this it is evident that our sedimentation data are comparable to those obtained in previous studies.

There is an apparent relationship between hydrography and phytoplankton development. Due to infrequent sampling we might have missed small-scale variations in the diatom numbers. Nevertheless, a general pattern of the development of diatoms is evident from the data (Fig. 2D). The period September to October, with low winds (Anthony pers. comm.) and relatively high temperature, is not conducive to vertical mixing (Fig. 2). The algal concentrations should decline to low levels (Radhakrishna et al. 1978, Banse 1984, 1986) as corroborated by the data on Chl a, diatom numbers (Fig. 2D) and sedimentation rates (Fig. 4). The subsequent period of November was characterized by low subsurface temperature, poorly oxygenated and nutrient rich water (Venugopalan 1988) below a shallow mixed layer (Fig. 2). The high levels of nutrients in close proximity to the surface layer set the stage for high algal concentrations. With the development of 
cold and dry northeast winds in December, the barrier of thermal stratification is removed thereby bringing nutrients into the surface layer (Ryther et al. 1966, Banse 1984, 1986, Venugopalan 1988). These changes were accompanied by an increase in the diatom numbers from December onwards with a maximum in February (Fig. 2D). In February, very high sedimentation of particulate material, relatively rich in plant pigments and biogenic silica (Fig. 4C, D), was observed. This indicates cessation of algal growth. Studies from other localities (Smetacek 1980, Peinert et al. 1982) have shown that sedimentation of phytoplankton cells does not take place to a larger extent as long as healthy populations are growing. The increase in cell sinking rate that accompanies the cessation of algal growth (Smetacek 1984), however, results in mass sedimentation of cells when grazing is low. In our investigation it is likely that nutrient depletion caused the sudden termination of diatom growth. Of the various nutrients, phosphates and silicates are unlikely to be limiting nutrients in these waters as their concentrations did not change significantly during the course of the study (Venugopalan 1988). In contrast to this, surface nitrate concentration was seldom high in these waters (ca 0.52 to $1.4 \mu \mathrm{g}$-at. $1^{-1}$ ), and showed a minimum level (ca 0.2 $\mu g$-at. $1^{-1}$ ) in February that may have been associated with the termination of diatom growth. Furthermore, zooplankton biomass, especially copepods, was also relatively low during this period (Bhat 1988). These factors could account for the high sedimentation rates of particulate material observed in February (Figs. 3 and 4 )

Organic matter deposited during the nonstratified period had low $\mathrm{POC} / \mathrm{Chl}$ a equiv. and $\mathrm{POC} / \mathrm{PSi}$ ratios (Figs. $4 \mathrm{C}, \mathrm{D}$ and $6 \mathrm{C}, \mathrm{D}$ ). These ratios are not very different from those obtained for phytoplankton (Parsons et al. 1961, Antia et al. 1963, Welschmeyer \& Lorenzen 1984, Brzezinski 1985). This suggests that fairly fresh organic matter derived from phytoplankton settled during this period. However, this organic matter had a relatively high $\mathrm{C} / \mathrm{N}$ (atomic) ratio, implying that it was poor in nitrogen (Fig. 6D). Low POC/Chl a equiv. and POC/PSi ratios were also recorded at $42 \mathrm{~m}$ during the stratified period particularly in September and October (Fig. 4C, D). A 2- to 4-fold increase in the concentration of chlorophyll a as compared with surface layer was observed below $25 \mathrm{~m}$ during this period (Venugopalan 1988). Export from a subsurface chlorophyll a maximum was perhaps responsible for the relatively low POC/Chl a equiv. and POC/PSi ratios of trap samples during the period of water column stratification. Recently, the importance of the subsurface chlorophyll maximum layer as a source of sedimentation to greater depth has been reported (Skjoldal \& Wassmann 1986).
The poorly oxygenated stratified water observed in November was associated with high sedimentation rates of TPM, POC and TCHO (Figs. 2, 4 and 5). Moreover, the organic matter deposited during this period had high POC/TPM, POC/Chl a equiv, and POC/PSi ratios (Fig. 4), suggesting sedimentation of resuspended highly degraded organic matter.

The marked decrease with depth in the sedimentation rates of chlorophyll a equiv. and PSi during the nonstratified period (Fig. 3E, F) suggests remineralization or dissolution either in the water column or the traps. In many other sedimentation studies, the decrease in sedimentation of these components has been attributed to mineralization or dissolution (Wassmann 1983, 1985, Skjoldal \& Wassmann 1986).

In general, the $\mathrm{AC}-\mathrm{CHO} / \mathrm{TCHO}$ ratio as well as the fluxes of AC-CHO showed a decrease with depth (Fig. 5; Table 2). The observed decrease implies that these compounds were utilized by heterotrophic organisms. The preferential consumption of $\mathrm{AC}-\mathrm{CHO}$ polysaccharides by heterotrophic organisms has been reported (Handa \& Tominaga 1969, Handa \& Yanagi 1969. Hitchcock 1977, Ittekkot et al. 1982, 1984, Liebezeit 1987. Tanoue \& Handa 1987). The decrease in AL$\mathrm{CHO} / \mathrm{TCHO}$ and an increase in $\mathrm{RS}-\mathrm{CHO} / \mathrm{TCHO}$ ratios at $62 \mathrm{~m}$ probably suggests the influence of resuspended sediments.

There were positive and highly significant $(p<0.001)$ correlations between the fluxes of TCHO and TPM. $\mathrm{POC}$, Chl a equiv. and PSi, suggesting common origin of these compounds. The observed relationships between the fluxes of TCHO and Chl a equiv. and PSi also suggest that diatoms were the major source of $\mathrm{TCHO}$

It has been suggested that large particles such as faecal pellets, faecal matter and marine snow play an important role in rapid transport of material to the sea floor (Honjo 1982, Asper 1987). The vehicle for transport of organic material to deeper water here appears to be sinking diatom cells, whether or not associated with faecal pellets, as indicated by the highly significant correlation coefficient obtained between the fluxes of PSi and POC (Fig. 7). The relation between sedimentation of PSi and organic material was highly significant $(r=0.90 ; p<0001)$ during the nonstratified period, but was not significant for the stratified period $(r=0.21 ; p>0.1)$. The low correlation observed for the stratified period is probably due to low numbers of diatoms and/or sedimentation of resuspended organic matter during this period.

Surface sediments at $78 \mathrm{~m}$ had organic carbon and TCHO percentages of dry weight of $0.72 \%$ and $0.16 \%$, respectively (National Institute of Oceanography - ONGC report unpubl.). Under these circumstances, the substantial supply of biogenic organic matter 
due to settling phytoplankton during February may have a stimulatory effect on the growth and reproduction of benthic organisms (Graf et al. 1982, 1983, Billett et al. 1983).

Acknowledgements. We thank Dr B. N. Desai, Director of the institute, for his constant encouragement throughout the study. We also thank Drs H. R. Skjoldal, B. T Hargrave, P. Wassmann and an anonymous referee for their critical comments and suggestions which helped us in revising the manuscript. We are especially grateful to Dr H. R. Skjoldal for his valued help and advice on the manuscript. We much appreciate partial financial assistance as well as facilities provided during our study by the Oil and Natural Gas Commission, Bombay.

\section{LITERATURE CITED}

Anderson, G. F. (1986). Silica, diatoms and a freshwater productivity maximum in the Atlantic costal plain estuaries, Chesepeake Bay. Estuar, cstl Shelf. Sci. 22: 183-197

Antia, N. J., McAllister, C. D., Parsons, T. R., Strickland, J. D. H. (1963). Further measurements of primary production using a large volume plastic sphere. Limnol. oceanogr. 8: 166-183

Asper, V. L. (1987). Measuring the flux and sinking speed of marine snow aggregates. Deep Sea Res. 34: 1-17

Banse, K. (1984). Overview of the hydrography and associated biological phenomenon in the Arabian Sea, off Pakistan. In: Haq, B. U., Milliman, J. D. (eds.) Marine geology and oceanography of Arabian Sea and coastal Pakistan. Van Nostrand Reinhold, New York, p. 271-303

Banse, K. (1986). Seasonality of phytoplankton chlorophyll in the central and northern Arabian Sea. Deep Sea Res. 34 $713-723$

Bhat, K. L. (1988). Studies on zooplankton with special reference to biofouling from the offshore region of Arabian Sea. Ph. D. thesis, Karnatak University

Bhosle, N. B., Dhople, V. M. (1988). Distribution of some biochemical compounds in the sediments of the Bay of Bengal. Chem. Geol. 67: 341-352

Bhosle, N. B., Wagh, A. B. (1989). Particulate carbohydrates in the Arabian Sea. Oceanologica Acta 12: 57-63

Billett, D. S. M., Lampitt, R. S., Rice, A. L., Mantoura, R. F. C. (1983). Seasonal sedimentation of phytoplankton to the deep-sea benthos. Nature, Lond. 302: 520-522

Bloesch, J., Burns, N. M. (1980). A critical review of sedimentation trap techniques. Schweiz. Z. Hydrol. 42: 15-55

Blomqvist, S., Kofoed, C. (1981). Sediment trapping - a subaquatic in situ experiment. Limmnol. Oceanogr. 26: $585-590$

Bodungen, B. v., Smetacek, V., Tilzer, M. M., Zeitzschel, B. (1986). Primary production and sedimentation during spring in the Antarctic Peninsula region. Deep Sea Res. 33: $177-194$

Brzezinski, M. A. (1985). The Si:C:N ratio of marine diatoms interspecific variability and the effect of some environmental variables. J. Phycol. 21: 347-357

Butman, C. A. (1986). Sediment trap biases in turbulent flow: results from a laboratory study. J. mar. Res. 44: 645-693

Carlberg, S. R. (1972). Cooperative research report. New Baltic manual, Göteborg. Series A No. 29: p. 142

Davies, J. M., Payne, R. (1984). Supply of organic matter to the sediment in the northern North Sea during a spring phytoplankton bloom. Mar. Biol. 78: 315-324
Dean, W E. Jr. (1974). Determination of carbonate and organic matter in calcareous sediments and sedimentary rocks by loss on ignition: comparison with other methods. J. sedim. Petrol. 44: 242-248

Degens, E. T., Ittekkot, V (1985). Particulate organic carbon an overview. In: Degens, E. T., Kempe, S., Herrera, R. (eds.) Transport of carbon and minerals in major world rivers. Mitt. Geol. Palaontol. Inst. Univ. Hamburg, SCOPE/ UNEP Sonderbd, p. 58

Deuser, W. G., Ross, E. H. (1980). Seasonal changes in the flux of organic carbon to the deep Sargasso Sea. Nature, Lond. 283: $364-365$

Deuser, W. G., Ross, E. H., Anderson, R. F. (1981). Seasonality in the supply of sediment to the deep Sargasso Sea and implications for the rapid transfer of matter to the deep ocean. Deep Sea Res. 28: 495-505

Ducklow, H. W., Hill, S. M., Gardner, W. D. (1985). Bacterial growth and decomposition of particulate organic carbon collected in sediment traps. Cont. Shelf Res, 4: 445-464

Falkowski, P. G., Vidal, J., Hopkins, T. S., Rowe, G. T., Whitledge, P. E., Harrison, W. G. (1983). Summer nutrient dynamics in the Middle Atlantic Bight: primary production and utilization of plankton carbon. J. Plankton Res. 5 $515-537$

Gardner, W D. (1980a). Sediment trap dynamics and calibration: a laboratory evaluation. J. mar. Res. 38: 17-39

Gardner, W D. (1980b). Field assessment of sediment traps. J. mar. Res. 38: 41-52

Graf, G., Bengtsson, W., Diesner, U., Schulz, R., Thede, H (1982). Benthic response to sedimentation of a spring phytoplankton bloom: process and budget. Mar. Biol. 67: 201-208

Graf, G., Schulz, R., Peinert, R., Meyer-Reil, L.-A. (1983). Benthic response to sedimentation events during autumn to spring at a shallow water station in the western Kiel Bight. Mar. Biol. 77: 235-246

Gulliksen, B. (1982). Sedimentation close to a near vertical rocky wall in Balsfjordel, northern Norway. Sarsia 67: $21-27$

Handa, N., Tominaga, H. (1969). A detailed analysis of carbohydrates in marine particulate matter Mar. Biol. 2: 228-235

Handa, N., Yanagi, T (1969). Studies on water extractable carbohydrates of the particulate matter from the northwest Pacific Ocean. Mar. Biol. 4: 197-210

Harding, G. C., Hargrave, B. T., Vass, W P., Pearre, S. Jr., Sheldon, R. W. (1987). Vertical flux of particulale matter by sedimentation and zooplankton movements in St. George's Bay, the Southern Gulf of St. Lawrence. Biol. Oceanogr. 4: 323-357

Hargrave, B. T., Burns, N. M. (1979). Assessment of sediment trap collection efficiency. Limmnol. Oceanogr. 24: $1124-1136$

Hargrave, B. T., Phillips, G. A. (1986). Dynamics of the benthic food web in St. Georges Bay, Southern Gulf of St. Lawrence. Mar. Ecol. Prog. Ser. 31: 277-294

Hargrave, B. T., Phillips, G. A., Taguchi, S. (1976). Sedimentation measurements in Bedford Basin, 1973-1974. Tech. Rep. Fish. Mar. Serv. Can. 608: 1-110

Hargrave, B. T., Taguchi, S. (1978). Origin of deposited material sedimented in a marine Bay. J. Fish. Res. Bd Can. 35: 1124-1136

Hitchcock, G. L. (1977). The concentration of particulate carbohydrate in a region of the West Africa upwelling zone during March 1974. Deep Sea Res. 24: 83-93

Honjo, S. (1978). Sedimentation of materials in the Sargasso Sea at a $5367 \mathrm{~m}$ deep station. J. mar. Res. 38: 53-97 
Honjo, S. (1982). Seasonality and interaction of biogenic and lithogenic particulate flux at the Panama Basin. Science 218: $883-884$

Ittekkot, V., Degens, E. T., Brockmann, U. (1982). Monosaccharide composition of acid hydrolizable carbohydrates in particulate matter during a plankton bloom. Limnol. Oceanogr 27: 770-776

Ittekkot, V., Degens, E. T., Honjo, S. (1984). Seasonality in the fluxes of sugars, amino acids, amino sugars to deep ocean: Panama Basin. Deep Sea Res. 31: 1071-1083

Kimmel, B. L., Axler, R. P., Goldman, J. C. R. (1977). A closing replicate sediment trap. Limnol Oceanogr. 22: 768-772

Knauer, G. A., Martin, J. H., Bruland, K. W. (1979). Fluxes of particulate carbon, nitrogen and phosphorous in the upper water column of the North East Pacific. Deep Sea Res. 26: 97-108

Liebezeit, G. (1987). Carbohydrate fluxes in the Bransfield Strait and Drake Passage. Mar. Chem. 20: 255-264

Liebezeit, G., Bodungen, B. v. (1987). Biogenic fluxes in the Bransfield Strait: planktonic versus macroalgal sources. Mar. Ecol. Prog. Ser. 36: 23-32

Lorenzen, C. J., Shuman, F. R., Bennett, J. T (1981). In situ calibration of a sediment trap. Limnol. Oceanogr 26: 580-585

Nelson, J. R., Beers, J. R., Eppley, R. W., Jackson, G. A., McCarthy, J. J., Souter, A. (1987). A particle flux study in the Santa Monica San Pedro Basin off Los Angeles: particle flux primary production and transmissometer study. Cont. Shelf Res. 7: 307-328

Parsons, T. R., Maita, Y., Lalli, C. M. (1984). A manual of chemical and biological methods for sea water analysis. Pergamon Press, Oxford, p. 157

Parsons, T R., Stephens, K., Strickland, J. D. (1961). On the chemical composition of eleven species of marine phytoplankters. J. Fish. Res. Bd Can. 18: 1.001-1016

Peinert, R., Saure, A., Stegmann, P., Stienen, C., Haardt, H., Smetacek, V (1982). Dynamics of primary production and sedimentation in coastal ecosystem. Neth. J. Sea Res. 16: $279-289$

Pennington, W. (1974). Seston and sediment formation in five Lake District lakes. J. Ecol. 62: 215-251

Prouse, N. J., Hargrave, B. T (1977). Chlorophyll, carbon and nitrogen in suspended and sedimented particulate matter in. St. Georges Bay, Nova Scotia. Tech. Rep. Fish. mar Serv, Can. 721. 1-69

Radhakrishna, K., Devassy, V P., Bhattathiri, P. M. A., Bhargava, R. S. (1978). Primary productivity in the northeastern Arabian Sea. Indian J. mar. Sci. 7: 137-139

Ryther, J. H., Hall, J. R., Pease, A. K., Bakul, A, Jones, M. M. (1966). Primary organic production in relation to the chemistry and hydrography of the western Indian Ocean Limnol. Oceanogr. 11. 371-380

Sasaki, H., Hattori, H. Nishizawa, S. (1988). Downward flux of particulate organic matter and vertical distribution of calanoid copepods in the Oyashio watrer in summer. Deep Sea Res. 35: 505-516

Sastry, J. S., D'Souza, R. S. (1972). Oceanography of the Arabian Sea during southwest monsoon season. Part III: Salinity. Indian J. meteorol. Geophys. 23: 479-490

Shetye, S. R. (1986). A model study of the seasonal cycle of the Arabian Sea surface temperature. J. mar Res. 44: 521-542

This article was presented by Dr H. R. Skjoldal, Bergen, Norway
Skjolddal, H. R., Wassmann, P. (1986). Sedimentation of particulate organic matter and silicium during spring and summer in Lindåspollene, Western Norway. Mar. Ecol. Prog. Ser 30: 49-63

Smart, M. M., Racla, R. G., Donnermeyer. G. N. (1983). Determination of total nitrogen in sediments and plants using persulphate digestion. Wat. Res, 1.7: 1207-1211

Smetacek, V. (1980). Annual cycle of sedimentation in relation to plankton ecology in western Kiel Bight. Ophelia, Suppl. $165-76$

Smetacek, V (1984). The supply of food to the benthos. In Fasham, M. J. (ed.) Flows of energy and materials in marine ecosystems: theory and practice. Plenum Press New York, p. 517-547

Smetacek, V (1985). Role of sinking in diatom life history cycles: ecological, evolutionary and geological significance. Mar. Biol. 84: 239-251

Smetacek, V., Bröckel, K. v., Zeitzschel, B., Zenk, W. (1978). Sedimentation of particulate matter during a phytoplankton bloom in relation to hydrographical regime. Mar. Biol. 47: 211-226

Sokal, R. R., Rohlf, J. F. (1981). Biometry, 2nd edn. W. H. Freeman and Co., San Francisco

Steel, J. H., Baird, I. E. (1972). Sedimentation of organic matter in a Scottish Sea loch. Memorie Ist. ital. Idrobiol. 29 (suppI.): 73-88

Stephens, K., Sheldon, R. W., Parsons, T R. (1967). Seasonal variations in the availability of food for benthos in a coastal environment. Ecology 48: 852-855

Strickland, J. D. H., Parsons, T R. (1972). A practical handbook of seawater analysis. Bull. Fish. Res. Bd Can. 167 $1-311$

Taguchi, S. (1982). Sedimentation of newly produced particulate organic matter in a subtropical inlet, Kaneohe Bay, Hawaii. Estuar cstl Shelf Sci. 14: 533-544

Tanoue, E. Handa, N. (1987). Monosaccharide composition of marine particles and sediments from the Bering Sea and northern North Pacific. Oceanologica Acta 10 91-99

Tsunogai, S., Uematsu, M., Tanaka, N., Harada, K. (1980). A sediment trap experiment in Funka Bay, Japan: upward flux of particulate matter in seawater Mar. Chem. 9: $321-334$

Venugopalan, V P. (1988). Studies on biofouling in the offshore waters of Arabian Sea. Ph. D. thesis, University of Bombay

Wassmann, P. (1983). Sedimentation of organic and inorganic particulate material in Lindåspollene, A stratified, landlocked fjord in western Norway. Mar. Ecol. Prog. Ser. 13: $237-248$

Wassmann, P. (1985). Sedimentation of particulate material in Nordásvannet, a hypertrophic, land-locked fjord in western Norway. Mar. Ecol. Prog. Ser. 22: 259-271

Webster, T J. M., Paranjape, M. A., Mann, K. H. (1975). Sedimentation of organic matter in St. Margaret's Bay, Nova Scotia. J. Fish. Res. Bd Can. 32: $1399-1407$

Welschmeyer, N. A., Lorenzen, C. J. (1984). Carbon-14 labelling of phytoplankton carbon and chlorophyll a carbon: determination of specific growth rates. Limnol. Oceanogr 29: $135-145$

Manuscriot first received: November 20, 1987

Revised version accepted: July 21, 1989 